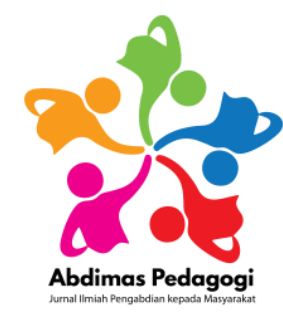

Abdimas Pedagogi: Jurnal Ilmiah Pengabdian kepada Masyarakat

Vol 2, No. 3, 2019, hlm.147-154

ISSN 2615-3122 (online)

ISSN 2548-6683 (print)

\title{
PEMANFAATAN DAN PEMBUATAN MEDIA MATEMATIKA DAN IPA BERBASIS INOVASI BAGI GURU SEKOLAH DASAR DI KOTA BLITAR
}

\author{
Esti Untari *, Yuniawatika, dan Lilik Bintartik \\ Jurusan KSDP, Fakultas Ilmu Pendidikan, Universitas Negeri Malang, Indonesia \\ Jl. Ir. Soekarno No. 1 Blitar \\ *e-mail: esti.untari.fip@um.ac.id
}

\begin{abstract}
The community service program in the City of Blitar aims to improve understanding of the use and making of mathematics and science media for elementary school teachers. Especially to be utilized in learning activities in mathematics and science that are based on innovation. The Target Group in this training activity is elementary school teachers in Blitar City with a total of 20 participants. The activity was carried out at the PP3 Computer Laboratory, State University of Malang in Blitar City. The method used in this training is lecture, question and answer, discussion, peer teaching and peer review. The results of community service activities produce products in the form of mathematical and natural media including bikastake media, human respiratory media, dakota media, and broken play media. Understanding of knowledge about the use of media can be seen from the results of the post test increased by $25 \%$.
\end{abstract}

Keywords: Utilization; media; mathematics, science

\begin{abstract}
Abstrak: Program pengabdian masyarakat di Kota Blitar ini bertujuan untuk meningkatkan pemahaman pengetahuan pemanfaatan dan pembuatan media matematika dan IPA bagi guru SD. Terutama untuk dapat dimanfaatkan dalam kegiatan pembelajaran matematika dan IPA yang berbasis inovasi. Kelompok Sasaran dalam kegiatan pelatihan ini guru Sekolah Dasar di Kota Blitar dengan jumlah 20 peserta. Kegiatan dilakukan di Laboratorium Komputer PP3 Universitas Negeri Malang di Kota Blitar. Metode yang digunakan dalam pelatihan ini ceramah, tanya jawab, diskusi, peer teaching dan peer review. Hasil kegiatan pengabdian menghasilkan produk berupa media matematika dan IPA meliputi media bikastake, media pernapasan manusia, media dakota, dan media permainan pecahan. Pemahaman pengetahuan tentang pemanfaatan media terlihat dari hasil post test mengalami peningkatan sebesar $25 \%$.
\end{abstract}

Kata kunci: Pemanfaatan; media; matematika, IPA 


\section{PENDAHULUAN}

Pembelajaran dapat dimaknai sebagai suatu kegiatan yang dilakukan oleh guru, sehingga tingkah laku peserta didik berubah ke arah yang lebih baik (Darsono, 2000: 24). Dalam proses belajar mengajar terutama di Sekolah Dasar media sangat penting. Media pembelajaran adalah alat bantu untuk membantu siswa dalam memahami suatu konsep saat belajar mengajar.

Menurut Hamalik dalam Arsyad (2011) mengemukakan bahwa pemakaian media pembelajaran dalam proses belajar-mengajar dapat membangkitkan keinginan dan minat yang baru, membangkitkan motivasi dan rangsangan kegiatan belajar, dan bahkan membawa pengaruhpengaruh psikologis terhadap siswa. Selain membangkitkan motivasi dan minat siswa, media pembelajaran juga dapat membantu siswa meningkatkan pemahaman, menyajikan data dengan menarik dan terpercaya, memudahkan penafsiran data, dan memadatkan informasi.

Pelajaran matematika dan IPA di SD tidak dapat terpisahkan oleh media pembelajaran, karena banyak materi pembelajaran matematika dan IPA yang sulit dijelaskan dengan buku saja. Penggunaan media dalam pelajaran matematika dan IPA di SD sangat bermanfaat, karena media memiliki fungsi-fungsi tertentu dalam proses belajar matematika dan IPA di SD. Di mana dalam pembelajaran baik matematika maupun IPA dibutuhkan media untuk mempermudah pemahaman siswa terhadap materi pelajaran yang membutuhkan contoh real atau pembelajaran konkretnya untuk menumbuhkan rasa ingin tahu yang tinggi. Dengan demikian media perlu untuk disiapkan dengan baik dan matang dalam kegiatan proses pembelajaran, karena peningkatan mutu pendidikan dapat tercapai dengan baik jika guru dapat menyiapkan proses pelaksanaan pembelajaran dengan baik dan matang (Yuniawatika, 2017)

Berdasarkan hasil evaluasi pengabdian sebelumnya dan wawancara singkat dengan beberapa guru SD dari 3 kecamatan yang ada di Kota Blitar terungkap bahwa para peserta pada umumnya sangat jarang menggunakan media dalam proses pembelajaran matematika dan IPA di kelas khususnya yang berupa alat peraga ataupun media-media inovatif lainnya. Menurut mereka sebetulnya alat peraga di SD ada, tetapi kebanyakan diantara mereka tidak mempunyai pemahaman yang cukup untuk menggunakan alat peraga tersebut. Siswa belajar matematika dan IPA lebih banyak melalui penjelasan secara langsung oleh guru yang didominasi dengan pemberian ceramah. Tentunya pembelajaran seperti ini tidak sesuai dengan tingkat perkembangan berpikir anak SD yang masih pada taraf operasional konkrit dan lambat laun akan membuat siswa bosan dan pembelajaran yang dialami siswa menjadi kurang bermakna.

Berdasarkan hasil analisis situasi tersebut, maka dilaksanakan kegiatan pengabdian kepada masyarakat tentang "Pemanfaatan Media dan Pelatihan Pembuatan Media Pembelajaran Matematika dan IPA Berbasis Inovasi bagi Guru-guru SD Kota Blitar". Pelatihan ini dilakukan dengan tujuan untuk mengembangkan kompetensi professional guru-guru SD di Kota Blitar yang menjadi mitra untuk dapat membuat dan memanfaatkan media pembelajaran matematika dan IPA berbasis inovasi sehingga dapat meningkatkan kualitas pembelajaran di SD. Pelatihan ini juga diharapkan dapat memotivasi para guru SD di Kota Blitar agar melaksanakan kegiatan pembelajaran dengan efektif, inovatif, dan efisien dengan menggunakan media pembelajaran yang berbasis saintifik dan mampu memanfaatkan media dalam pembelajaran.

\section{METODE}

Kegiatan pengabdian ini dilaksanakan pada tanggal 18-21 Juli 2018 di Laboratorium Komputer Kampus PP3 Universitas Negeri Malang di Kota Blitar. Kegiatan pelatihan ini diikuti oleh 20 guru SD yang tergabung dalam kelompok kerja guru di Kota Blitar. Para peserta terdiri dari guru SD kelas IV mewakili tiga kecamatan yang terdapat di Kota Blitar, dengan harapan para 
peserta dapat menyebarluaskan ilmu yang didapatkan di masing-masing kecamatan. Metode yang digunakan dalam pelatihan ini meliputi metode ceramah, tanya jawab, pelatihan, pemberian tugas, diskusi, presentasi, peer teaching, dan peer review. Tahapan pelatihan terdiri dari 3 tahap yaitu perencanaan, pelaksanaan dan evaluasi.

\section{Tahap Perencanaan}

Kegiatan perencanaan dilakukan dengan berkoordinasi dengan dinas pendidikan kota Blitar untuk mengurus ijin kegiatan. Sedangkan tim pengabdian mempelajari terlebih dahulu mengenai media pembelajaran matematika dan IPA yang ada di kelompok mitra. Kemudian melakukan inventaris contoh-contoh permasalahan yang dihadapi guru dalam memanfaatkan media baik media matematika dan IPA. Tim pengabdian membuat contoh pemanfaatan media pembelajaran matematika dan IPA di SD dan membuat media pembelajaran matematika dan IPA di SD. Tim juga mempersiapkan materi untuk kegiatan agar pelaksanaan pelatihan dapat terarah.

\section{Tahap Pelaksanaan}

Kegiatan pelaksanaan dilaksanakan selama 4 hari. Hari pertama tim memberikan materi tentang pemanfaatan media matematika. Hari kedua tim memberikan materi tentang pemanfaatan media IPA. Hari ketiga peserta diskusi dan membuat media yang berbasis inovasi. Hari keempat peserta melakukan peer teaching dan tim mereview. Berikut merupakan materi pelatihan beserta metode yang digunakan pada Tabel 1 .

Tabel 1. Materi dan Fasilitator Kegiatan Pengabdian

\begin{tabular}{llll}
\hline No. & \multicolumn{1}{c}{ Materi kegiatan } & \multicolumn{1}{c}{ Pelaksana } & \multicolumn{1}{c}{ Metode } \\
\hline 1. & $\begin{array}{l}\text { Pembukaan dan Pengenalan media dalam } \\
\text { pembelajaran matematika }\end{array}$ & Yuniawatika, S.Pd.,M.Pd & $\begin{array}{l}\text { Ceramah, tanya jawab, } \\
\text { dan diskusi }\end{array}$ \\
2 & $\begin{array}{l}\text { Pengenalan media dalam pembelajaran } \\
\text { Ceramah, tanya jawab, }\end{array}$ & Dra. Lilik Bintartik, M.Pd & $\begin{array}{l}\text { dan diskusi } \\
\text { dPA }\end{array}$ \\
3 & Membuat media matematika dan IPA & Esti Untari, S. Pd., M.Pd & $\begin{array}{l}\text { Diskusi dan Praktek } \\
\text { Simulasi }\end{array}$ \\
\hline
\end{tabular}

\section{Evaluasi dan Refleksi}

Tahap evaluasi dilakukan untuk mengetahui pemahaman guru dalam pemanfaatan media matematika dan IPA. Evaluasi dalam kegiatan pengabdian ini dibagi menjadi evaluasi awal, evaluasi proses, evaluasi akhir, dan refleksi. Evaluasi awal dilakukan untuk mengetahui kemampuan awal peserta sebelum mengikuti kegiatan pengabdian. Melalui evaluasi awal ini kita dapat mengetahui kemampuan peserta sebelum ditingkatkan. Teknik evaluasi yang diberikan berupa pretes. Evaluasi proses meliputi keaktifan peserta pelatihan sebagai indikator dan tolak ukur, yaitu kehadiran yang dilihat dari daftar hadir presensi setiap pertemuan dan aktivitas dilihat dari keterlibatan peserta dalam berdiskusi, dan tanya jawab. Teknik evaluasi menggunakan observasi dan tanya jawab. Sedangkan evaluasi berikutnya yaitu evaluasi akhir dilakukan dengan memberikan soal postes untuk melihat peningkatan penguasaan materi setelah diberikan pelatihan tentang pemanfaatan media matematika dan IPA. Selain itu peserta diberikan angket untuk melakukan refleksi. Refleksi dilakukan bersama antara tim dan peserta (guru mitra). Hal ini dilakukan untuk mengetahui seluruh proses pelaksanaan kegiatan.

\section{HASIL DAN PEMBAHASAN}

Kegiatan ini dilaksanakan selama empat hari di laboratorium komputer kampus PP3 UM yang beralamat di Jl. Ir. Soekarno No 1 Kota Blitar. Kegiatan ini diikuti oleh 20 orang guru SD yang berasal dari tiga kecamatan yang ada di Kota Blitar yaitu Kepanjenkidul, Sananwetan, dan sukerjo. Selain itu, para peserta berasal dari guru kelas yang bervariatif baik kelas rendah maupun 
kelas tinggi. Pelaksanaan kegiatan pelatihan ini secara umum berjalan lancar. Kegiatan ini dibantu oleh 2 mahasiswa PGSD semester 5. Setelah kegiatan ini diharapkan guru dapat memanfaatkan media matematika dan IPA dengan baik di Sekolah. Gambaran hasil pelatihan pada setiap tahapan dapat disampaikan sebagai berikut.

\section{Koordinasi dengan pihak terkait}

Tim pengabdian melakukan koordinasi pihak terkait yaitu koordinator guru dalam KKG di Kota Blitar dan mengurus perizinan pelaksanaan kegiatan pengabdian. Koordinasi dengan tim pengabdian yaitu dosen dan mahasiswa untuk mempersiapkan materi dan alat-alat yang digunakan dalam kegiatan pelatihan.

\section{Pelaksanaan Pelatihan}

Kegiatan pelatihan dilaksanakan secara bertahap selama 4 hari, bertempat di Laboratorium Komputer Kampus 3 di Kota Blitar. Adapun jadwal kegiatan terlampir di table 2. Kegiatan Pelatihan dibuka oleh Kepala Subdivisi Peningkatan Mutu Pendidikan dan Tenaga Pendidikan Kota Blitar Bapak Muhammad Arifin, M.Pd. Beliau memberikan pengarahan dengan pelatihan ini diharapkan guru dapat memanfaatkan pelatihan ini dengan baik dan menerapkan untuk pembelajaran di Sekolah masing-masing.

Setelah sambutan, kegiatan dimulai dengan dilakukan pretest untuk mengetahui kemampuan peserta tentang pemanfaatan media pembelajaran matematika dan IPA yang akan disampaikan. Kemudian dilanjutkan penyampaian materi oleh tim pengabdian, tentang pemanfaatan media matematika seperti pada gambar 1 . Materi pada pertemuan ini selain mengenai media, pemateri membahas mengenai materi dan kesalahan-kesalahan konsep matematika yang sering terjadi pada siswa yang perlu diperbaiki salah satunya dengan memanfaatkan media matematika. Beberapa media yang dibahas pada kegiatan pengabdian ini yaitu yang berhubungan dengan materi pecahan, bangun datar, bangun ruang, bilangan bulat, dan sebagainya. Metode yang digunakan ialah ceramah, diskusi, tanya jawab, dan analisis masalah (analisis kasus). Analisis masalah ini terutama masalah yang dihadapi oleh guru mengenai materi matematika dan miskonsepsi yang terjadi pada siswa maupun pada guru.

Kegiatan hari ke-2 penyampaian materi pemanfaatan media IPA, guru sangat antusias dalam mengikuti kegiatan ini seperti pada gambar 2. Pada gambar 2 peserta diajak untuk membuktikan bahwa udara terdapat dimana-mana. Selain itu juga peserta diajak untuk membuktikan bahwa suhu air mendidik tidak selalu 1000C tetapi sesuai dengan ketinggian daerah masing-masing. Selain itu peserta juga diajak oleh fasilitator untuk membuktikan tentang udara yang mengembang dan menyusut. Percobaan yang dilakukan dengan meletakkan botol yang pada bagian mulut botol diberi balon dan diletakkan didalam air panas dan air es, terlihat perbedaan bahwa botol yang diletakkan dalam air panas balon akan mengembang sedangkan botol yang diletakkan dalam air es balon mengempir. Hal ini membuktikan bahwa udara apabila dipanaskan akan mengembang dan didinginkan akan menyusut.

Sedangkan pada gambar 3, salah satu peserta menunjukkan hasil karya inovasinya. Media yang telah dibuat untuk membuktikan terjadinya perubahan bentuk energi listrik. Media tersebut terbuat dari barang yang kurang dimanfaatkan oleh kita antara lain telepon mainan, dinamo bekas dan triplek bekas. 
Tabel 2. Jadwal Kegiatan Pengabdian

\begin{tabular}{|c|c|c|c|c|}
\hline No. & $\begin{array}{c}\text { Hari / } \\
\text { tanggal }\end{array}$ & Waktu & Materi kegiatan & Pelaksana \\
\hline 1. & Hari ke-1 & $\begin{array}{l}08.00-08.15 \\
08.15-08.30\end{array}$ & $\begin{array}{l}\text { Pembukaan } \\
\text { Sambutan tim pelaksana }\end{array}$ & $\begin{array}{l}\text { Tim } \\
\text { Dra. Lilik Bintartik, M.Pd }\end{array}$ \\
\hline & & $\begin{array}{l}08.45-09.00 \\
09.00-09.15 \\
09.30-09.45 \\
09.45-11.45\end{array}$ & $\begin{array}{l}\text { Sambutan Kepala Dinas Pendidikan } \\
\text { Dasar Kota Blitar } \\
\text { Pembukaan kegiatan } \\
\text { Doa Pembukaan } \\
\text { Pre test } \\
\text { Istirahat } \\
\text { Pengenalan media dalam } \\
\text { pembelajaran matematika }\end{array}$ & $\begin{array}{l}\text { Kepala Dinas (yang } \\
\text { mewakili) } \\
\text { Tim } \\
\text { Tim } \\
\text { Yuniawatika, S.Pd.,M.Pd }\end{array}$ \\
\hline & & $\begin{array}{l}11.45-12.30 \\
12.30-14.15 \\
\end{array}$ & $\begin{array}{l}\text { Ishoma } \\
\text { Pemanfaatan media matematika }\end{array}$ & Yuniawatika, S.Pd.,M.Pd \\
\hline 2 & Hari ke-2 & $\begin{array}{l}08.00-09.00 \\
09.45-10.30 \\
10.30-12.30 \\
\\
12.30-13.30 \\
13.30-14.15\end{array}$ & $\begin{array}{l}\text { Pengenalan media dalam } \\
\text { pembelajaran IPA } \\
\text { Istirahat } \\
\text { Pengenalan media dalam } \\
\text { pembelajaran IPA } \\
\text { Ishoma } \\
\text { Pemanfaatan media IPA }\end{array}$ & Dra. Lilik Bintartik, M.Pd \\
\hline 3 & Hari ke-3 & $\begin{array}{l}08.00-08.30 \\
08.30-10.00 \\
10.00-10.30 \\
10.30-12.30 \\
12.30-13.30 \\
13.30-14.15\end{array}$ & $\begin{array}{l}\text { Pembagian kelompok } \\
\text { Membuat media matematika dan } \\
\text { IPA } \\
\text { Istirahat } \\
\text { Membuat media matematika dan } \\
\text { IPA } \\
\text { Ishoma } \\
\text { Membuat media matematika dan } \\
\text { IPA }\end{array}$ & $\begin{array}{l}\text { Esti Untari, S. Pd., M.Pd } \\
\text { Esti Untari, S. Pd., M.Pd }\end{array}$ \\
\hline 4 & Hari ke-4 & $\begin{array}{c}08.00-09.45 \\
09.45-10.00 \\
10.00-12.15 \\
12.15-13.00 \\
13.00-13.30 \\
13.30-14.15 \\
\quad \text { Selesai }\end{array}$ & $\begin{array}{l}\text { Peer teaching } \\
\text { Istirahat } \\
\text { Peer reviewer } \\
\text { Ishoma } \\
\text { Postest dan Refleksi } \\
\text { Penutupan Kegiatan }\end{array}$ & $\begin{array}{l}\text { Tim } \\
\text { Tim } \\
\text { Tim } \\
\text { Tim }\end{array}$ \\
\hline
\end{tabular}

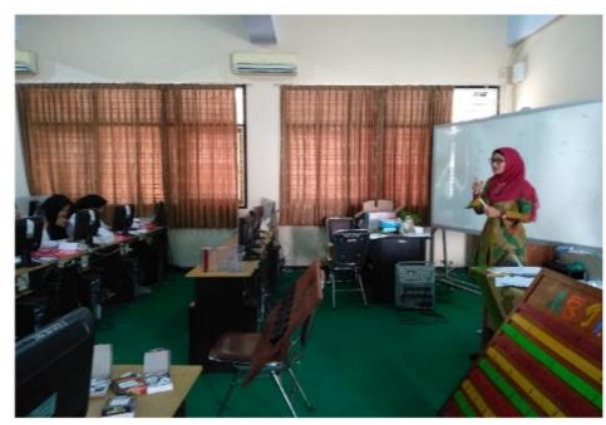

Gambar 1. Kegiatan Penyampaian materi pemanfaatan media matematika 


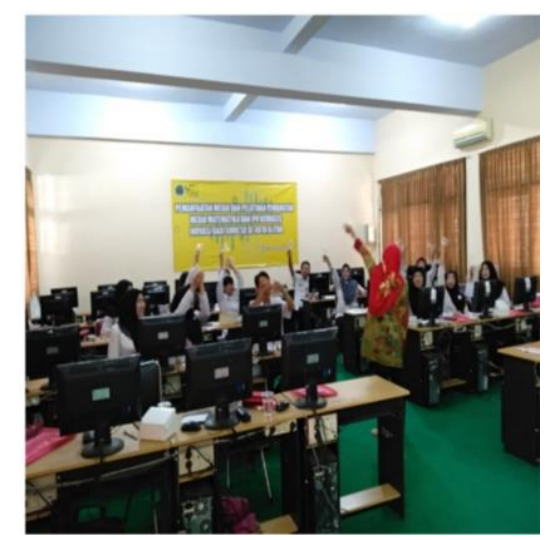

\section{Gambar 2. Kegiatan Penyampaian materi pemanfaatan media IPA}

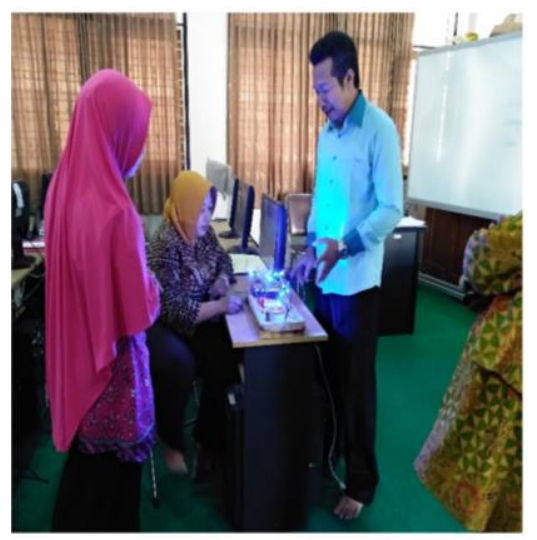

Gambar 3. Salah satu peserta mempraktekkan media yang dibuat

Kegiatan hari ke-3 pendampingan pembuatan media yang berbasis inovasi. Kegiatan yang dilakukan oleh peserta selain membuat media yang berbasis inovasi, fasilitator juga memberikan materi tentang media yang berbasis IT, dengan memperkenalkan software yang dapat digunakan dalam pembelajaran yaitu software lectora inspire. Lectora inspire dapat membuat dan menyajikan materi ajar dengan tanpa harus melakukan programming. Software ini dilengkapi dengan software flypaper, Camtasia dan snagit, serta media library dan template lectora yang cukup lengkap. Materi yang disajikan bisa berupa teks, grafik, animasi, game video maupun suara. Lectora inspire menyediakan 8 tipe pertanyaan seperti pilihan ganda, benar/salah, mendojohkan, uraian singkat, drag and drop, hot spot, essay dan fill in blank yang mudah diterapkan. Evaluasi yang terdapat dalam lectora inspire, dapat menampilkan feed back dan skor yang bisa diketahui secara langsung, sehingga memudahkan para guru untuk melakukan penilaian.

Kegiatan hari ke-4 peer teaching dan peer reviewer terhadap media yang telah dibuat oleh peserta. Salah satu peserta pelatihan mempraktekkan media yang telah dibuat yang memanfaatkan bahan-bahan yang ada disekitar untuk menjelaskan tentang perubahan energi seperti terlihat pada gambar 3.

\section{Evaluasi dan Refleksi}

Hasil kegiatan ini mencakup beberapa komponen yaitu: (1) keberhasilan target jumlah peserta kegiatan pengabdian yang hadir yakni 20 orang guru yang mewakili tiga kecamatan yang terdapat pada kota Blitar; (2) ketercapaian target materi yang diberikan kepada peserta; (3) ketercapaian luaran kegiatan pendampingan ini yakni media pembelajaran yang dibuat oleh guru; dan (4) 
ketercapaian pelaksanaan pretes dan postes. Berdasarkan hasil kegiatan tersebut menunjukkan bahwa kegiatan pengabdian ini dapat dinyatakan berhasil. Berdasarkan hasil pre test dan post test yang telah diberikan sebelum dan sesudah kegiatan pelatihan menunjukkan terdapat peningkatan pemahaman peserta terhadap pemanfaatan media matematika dan IPA hal ini terlihat dari hasil post test yang mengalami peningkatan dari nilai rata-rata pre test 65,55 menjadi 90,05 . Sedangkan hasil angket ditinjau dari kebermanfaatan kegiatan pelatihan, waktu pelaksanaan pelatihan, waktu mengerjakan tugas ketika pelatihan, penjelasan narasumber dan makalah yang telah diberikan marasumber kepada peserta dapat ditunjukkan pada gambar 4.

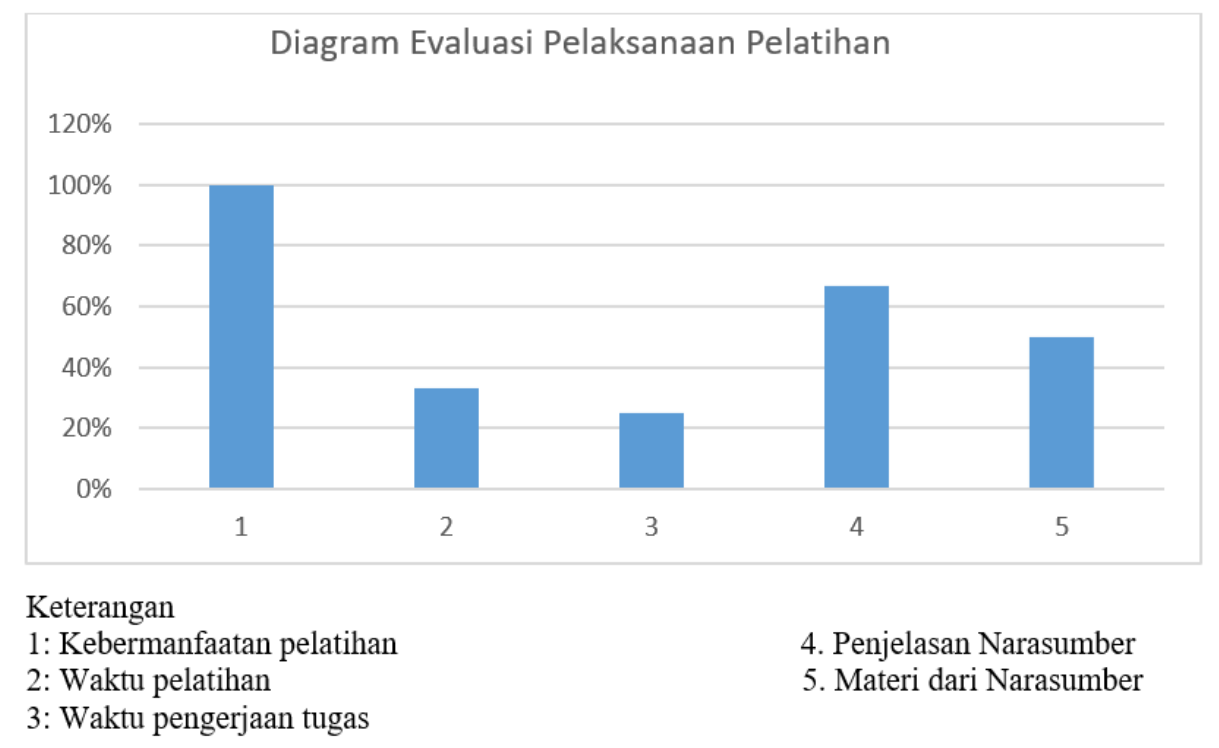

\section{Gambar 3. Diagram evaluasi pelaksanaan pelatihan}

Berdasarkan diagram tersebut menunjukkan persentase sebesar $100 \%$ peserta menyatakan bahwa pelatihan ini sangat bermanfaat untuk dapat meningkatkan pemahaman terhadap materi matematika dan IPA. Sedangkan waktu pelatihan menunjukkan persentase sebesar $30 \%$ peserta berpendapat bahwa waktu pelaksanaan masih perlu ditambahkan lagi. Dalam pengerjaan tugas yang diberikan pemateri kepada peserta menunjukkan persentase sebesar $23 \%$ waktu dalam mengerjakan tugas perlu ditambah lagi. Penjelasan dari narasumber menunjukan persentase sebesar $65 \%$ bahwa pemberian materi yang disampaikan narasumber sudah baik. Selain itu materi yang telah diberikan oleh narasumber sangat menunjang kegiatan pelatihan terlihat pada diagram menunjukkan persentase sebesar $50 \%$.

Dalam proses pembelajaran, media yang digunakan guru harus sesuai dengan tujuan pembelajaran yang telah ditetapkan sehingga mampu merangsang dan menumbuhkan minat siswa dalam belajar yang pada akhirnya akan mampu mempercepat proses pemahaman siswa terhadap isi pembelajaran (Nugraha \& Sudiyono, 2018). Dengan demikian guru harus memiliki pengetahuan dan pemahaman yang cukup tentang media pembelajaran, yang menurut Hamalik (1994) meliputi: 1) media sebagai alat komunikasi guna lebih mengefektifkan proses pembelajaran; 2) fungsi media dalam rangka mencapai tujuan pendidikan; 3) seluk beluk proses pembelajaran; 4) hubungan antara metode mengajar dan media pendidikan; 5) nilai atau manfaat media pembelajaran dalam pembelajaran; 6) pemilihan dan penggunaan media pembelajaran; 7) berbagai jenis alat dan teknik media pendidikan; 8) berbagai jenis alat dan teknik media pembelajaran; 9) usaha inovasi dalam media pendidikan. 
Pelaksanaan kegiatan pengabdian tentang pemanfaatan media pembelajaran matematika dan IPA berjalan dengan baik dan lancar. Dalam setiap kegiatan diikuti dengan antusias oleh peserta pelatihan. Respon guru terhadap kegiatan ini juga baik karena guru akan menerapkan yang telah didapatkan dalam pembelajaran di Sekolah. Terlihat pada angket yang telah diberikan sebagian besar peserta berpendapat pelathan ini sangat bermanfaat bagi peserta. Selain itu peserta berharap pelatihan sejenis juga perlu dilaksanakan pada mata pelajaran yang lain. Peserta juga sangat antusias ketika dikenalkan dengan media yang berbasis IT.

Sedangkan hambatan dalam pelaksanaan kegiatan ini, pada kegiatan penyampaian materi tentang software Lectora Inspire dimana dalam mengintal software tersebut memerlukan waktu yang lama dan tidak semua laptop yang digunakan bisa secara otomatis bisa digunakan sehingga peserta merasa bosan dan memerlukan waktu yang lama.

\section{SIMPULAN}

Kegiatan pengabdian kepada masyarakat yang sudah dilakukan berupa pelatihan memanfaatkan media matematika dan IPA dalam pembelajaran di kelas dan membuat media berbasis inovasi dapat dengan memanfaaatkan barang bekas ataupun menggunakan software lectora inspire. Berdasarkan hasil diskusi dengan guru peserta pelatihan mereka sangat mengharapkan pelatihan-pelatihan seperti pemanfaatan media matematika dan IPA dengan media sederhana dan pemanfaatan software dalam pembuatan media. Namun kegiatan ini diharapkan tidak berakhir pada kegiatan pengabdian, tetapi bisa kegiatan yang berkelanjutan dan adanya pendampingan untuk mendesiminasikan ke masing-masing kecamatan.

\section{DAFTAR RUJUKAN}

Arsyad, A. (2011). Media Pembelajaran. Jakarta: PT Raja Grafindo Persada

Darsono. (2000). Belajar dan Pembelajaran. Semarang: IKIP Press

Hamalik, O. (1994). Media pembelajaran. Jakarta: Raja Grafindo Persada.

Nugraha, D. A., \& Sudiyono, S. (2018). Pelatihan Dan Pendampingan Pembuatan Media

Pembelajaran Interaktif Menggunakan Autoplay Media Studio Bagi Guru-Guru SDN

Merjosari 1. Jurnal Terapan Abdimas, 3(2), 182-187.

http://lp2m.um.ac.id/pengabdian-2015/

http://www.jawapos.com/baca/artikel/13861/inovasi-pendidikan-wali-kota-blitar

Yuniawatika \& Nuraini, N. L. S. 2017. Pendampingan Penyusunan Rencana Pelaksanaan

Pembelajaran Tematik Scientific Dengan Pembelajaran Karakter Terintegrasi. Abdimas

Pedagogi, 1(1). 